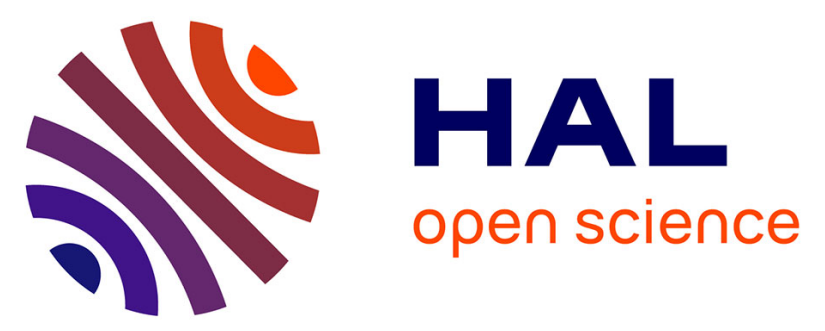

\title{
New insights on the selective electroconversion of the cellulosic biomass-derived glucose at PtAu nanocatalysts in an anion exchange membrane fuel cell
}

Charly Lemoine, Yaovi Holade, Lionel Dubois, Teko Napporn, Karine Servat, Kouakou Kokoh

\section{To cite this version:}

Charly Lemoine, Yaovi Holade, Lionel Dubois, Teko Napporn, Karine Servat, et al.. New insights on the selective electroconversion of the cellulosic biomass-derived glucose at PtAu nanocatalysts in an anion exchange membrane fuel cell. Journal of Electroanalytical Chemistry, 2021, 887, pp.115162. 10.1016/j.jelechem.2021.115162 . hal-03441719

\author{
HAL Id: hal-03441719 \\ https://hal.science/hal-03441719
}

Submitted on 29 Nov 2021

HAL is a multi-disciplinary open access archive for the deposit and dissemination of scientific research documents, whether they are published or not. The documents may come from teaching and research institutions in France or abroad, or from public or private research centers.
L'archive ouverte pluridisciplinaire HAL, est destinée au dépôt et à la diffusion de documents scientifiques de niveau recherche, publiés ou non, émanant des établissements d'enseignement et de recherche français ou étrangers, des laboratoires publics ou privés. 


\title{
New insights on the selective electroconversion of the cellulosic biomass-derived glucose at PtAu nanocatalysts in an anion exchange membrane fuel cell
}

Charly Lemoine ${ }^{\mathrm{a}}$, Yaovi Holade ${ }^{\mathrm{b}}$, Lionel Dubois ${ }^{\mathrm{c}}$, Teko W. Napporn ${ }^{\mathrm{a}}$, Karine Servat ${ }^{\mathrm{a}}$, Kouakou B. Kokoh ${ }^{\text {* }}$

${ }^{a}$ Université de Poitiers, IC2MP UMR-CNRS 7285, 86073 Poitiers Cedex 9, France.

b Institut Européen des Membranes, IEM-UMR 5635, Univ Montpellier, ENSCM, CNRS, 34090 Montpellier, France.

${ }^{\mathrm{c}}$ Univ. Grenoble Alpes, CEA, CNRS, IRIG, SyMMES, F-38000 Grenoble

*Corresponding author: boniface.kokoh@univ-poitiers.fr (K.B. Kokoh)

ORCID: 0000-0002-5379-7792

\begin{abstract}
Cellulosic biomass, which is basically a polymer of glucose, is the most abundant organic polymer on earth and there is significant interest in the development of advanced materials for its valorization through the waste-to-energy and water-to-chemical scenarios. Hence, a precise investigation of the monomer (glucose) electrooxidation in electrochemical reactors is a key starting point to tackle the whole cellulose and ultimately the entire biomass. To this end, we report herein new insights about the operation of a cogeneration direct alkaline glucose fuel cell (which includes an anion exchange membrane) that simultaneously produces electricity and mainly gluconate as the reaction product. The AuPt nanocatalysts of 3-5 nm particle size finely dispersed onto reduced graphene oxide (rGO) at a 20 wt.\% metal loading are obtained from an organic surfactant-free method, so-called the bromide anion exchange (BAE).
\end{abstract}


Specifically, the electroanalytical investigation carried out with high-performance liquid ionic chromatography (HPLIC) and liquid chromatography coupled to mass spectrometry (LC-MS) demonstrate no carbon-carbon bond cleavage occurs, which represents an advance towards a $\mathrm{CO}_{2}$-free biomass valorization process. The comparison of the results commonly obtained in a three-electrode half-cell with those in an anion exchange membrane fuel cell shows that the trends in selectivity are the same. The fuel cell operation produces gluconate via a twoelectron transfer process at $90 \%$ selectivity and $65 \%$ Faradaic efficiency. In addition to gluconate, glucuronate is also observed; both compounds are high value-added chemicals. This work contributes towards the engineering of novel electrocatalytic interfaces for the valorization of the surplus biomass into energy and chemicals.

\section{Keywords}

Glucose electrooxidation, Fuel cell, Anion exchange membrane, Reduced graphene oxide, Biomass 


\section{Introduction}

Glucose has proven to be of particular interest in the health and biomedical fields. Indeed, this natural and renewable sugar of biological systems constitutes a stock of energy, theoretically inexhaustible [1-5]. It is therefore a fuel of choice for fuel cells when it is oxidized at the anode, while oxygen is reduced at the cathode. Actually, glucose/oxygen fuel cells have emerged as an alternative solution to commonly used batteries because they make it possible to avoid the repetition of surgical operations needed to renew the lithium in the batteries, and to use a totally non-toxic fuel. In addition, these devices can be miniaturized to power biomedical devices such as insulin pumps, pacemakers or directly act as sensors for glucose the level management [6-10]. The glucose oxidation is naturally catalyzed by biological catalysts, which suffer from long-term stability and impossibility of operating at strong alkaline $\mathrm{pH}$ where high current densities can be extracted. Specifically, the use of abiotic catalysts appears to be promising to improve the lifetime of implantable glucose fuel cells, which are mostly enzymatic and suffer from the lack of enzyme stability $[11,12]$. Gold is known for its remarkable electrochemical activity and excellent selectivity towards the oxidation of a hemiacetalic function to gluconate [13,14]. Platinum, on the other hand, is the reference catalytic material for many electrocatalytic reactions, the dehydrogenating of the anomeric carbon of glucose can be achieved at very low potential, but deactivates rapidly [1518]. Hence, a bimetallic electrocatalyst is expected to have a good balance between activity, selectivity and durability. Because glucose is the main monomer of cellulose that represents the majority of the biomass $[19,20]$, one of the emerged scenarios is to target a selective electrooxidation of glucose in order to simultaneously produce electrical energy and chemicals. Such study as a model reaction will further enable to target the direct cellulosebased devices [21,22]. Because of their biocompatibility, gluconate salts (US7618664) are of 
paramount importance in several areas, the two-electron selectivity towards gluconate or gluconic acid is highly desired [23]. It has been demonstrated that the glucose oxidation at $\mathrm{Au}$ - and Pt-based nanocatalysts produced gluconate as the main product in alkaline conditions [24-28]. The reaction mechanism leading to this product involves gluconolactone as an intermediate through the glucose dehydrogenation [25,28]. Wojcieszak et al. [29] also found that glucuronate is formed at cesium-promoted gold nanocatalysts. Furthermore, glucarate is obtained as a minor product on gold and platinum electrodes modified by several adatoms [30]. To date, there is not experimental proof that this selectivity in half-cell will be kept unchanged during the alkaline glucose fuel cell process catalyzed by supported AuPt nanocatalysts, which are the only electrodes capable of delivering a high current density.

Furthermore, metal nanoparticles fixed and stabilized on supports allow to have good dispersion and to take benefits of the particle-support interaction, which means that the nature of the support has an effect on the electrochemical activity and the stability of the nanocatalysts [31]. Carbon-based supports are widely used in heterogeneous catalysis due to their cost-effective and performance nature. In order to optimize these two parameters together, carbonaceous supports derived from graphene are increasingly studied in the field of electrocatalysis, given the remarkable properties of this material: bi-dimensional network of $\mathrm{sp}^{2}$ hybridized carbon atoms, large specific surface area, high electrical conductivity and mechanical resistance [32-36]. The Bromide Anion Exchange (BAE) method was reported for the preparation of metallic nanocatalysts onto a Vulcan substrate [37]. More conductive material such as graphene layer was used as substrate for electrodepositing $\mathrm{Au}$ and $\mathrm{Pt}$ nanocatalysts for glucose oxidation [38]. BAE method was also performed to disseminate catalysts nanoparticles on reduced graphene oxide (rGO) [39]. The latter approach method is a surfactant-free synthesis based on the anion exchange between the bromide and the chloride anions before reduction by sodium borohydride. It allows obtaining well-dispersed and small- 
sized nanoparticles without organic molecules that block the access to the entire active sites. Even though we previously reported the fuel cell performance of the AuPt catalysts synthesized by the BAE method [28, 39], a precise electroanalytic investigation about the distribution of the reaction products is still missing. Indeed, fuel cells are expected to operate either in galvanostatic or potentiostatic modes and there is no information about the implications resulting from such operation. This is a key information for practical application because in electrocatalysis, the performance in half-cell reaction is not necessary the expected one with the whole fuel cell or electrolyzer [40]. In the present paper, gold and platinum nanoparticles were prepared onto Vulcan and rGO for an in-depth electroanalytical investigation by both half-cell and direct alkaline glucose fuel cell experiments. Ex situ and real-time ion chromatography, and liquid chromatography coupled with mass spectrometry analysis of the sampled solution extracted from the fuel cell operation demonstrated that glucose is mainly electrooxidized on its carbon at the C1-position (selectivity of 90\%) leading to gluconic acid. Glucuronic acid was also obtained as a minor product following the glucose electrooxidation at the C6-position. These two oxidation products of high interest open new windows for the electrochemical reforming of the cellulosic biomass.

\section{Materials and Methods}

\subsection{Reagents and materials}

Carbon Vulcan XC-72R was obtained from Cabot. Graphite particles (BET surface area of $\left.750 \mathrm{~m}^{2} \mathrm{~g}^{-1}\right), \mathrm{H}_{2} \mathrm{SO}_{4}(95 \%), \mathrm{HAuCl}_{4} \cdot 3 \mathrm{H}_{2} \mathrm{O}$ (99.9\%), $\mathrm{H}_{2} \mathrm{PtCl}_{6} \cdot 6 \mathrm{H}_{2} \mathrm{O}(99.9 \%), \mathrm{NaBH}_{4}(99 \%)$, D-(+)-glucose (99.5\%), KOH (90\%), and Nafion ${ }^{\circledR}$ suspension (5 wt.\%) were purchased from Sigma-Aldrich. $\mathrm{KBr}(99 \%)$ was purchased from Fisher Scientific. $\mathrm{HNO}_{3}(65 \%)$ and filters Durapore Membrane (hydrophilic PVDF, $0.22 \mu \mathrm{m}, 47 \mathrm{~mm}$ ) were purchased from Merck. HCl 
(37\%) was purchased from VWR. The used water was ultrapure and obtained from a Milli-Q Millipore source $\left(18.2 \mathrm{M} \Omega \mathrm{cm}\right.$ at $\left.20^{\circ} \mathrm{C}\right)$.

\subsection{Preparation of carbon supports}

Carbon Vulcan XC-72R underwent a thermal treatment at $400{ }^{\circ} \mathrm{C}$ under $\mathrm{N}_{2}$ atmosphere for 4 $\mathrm{h}$ according to reported procedure [41]. To prepare rGO substrate, graphite powder (16 g) was dispersed, under stirring, in $400 \mathrm{~mL}$ of $\mathrm{H}_{2} \mathrm{SO}_{4}$ at $200{ }^{\circ} \mathrm{C}$. After $7 \mathrm{~h}$, the solution was cooled down to room temperature. Afterwards, ultrapure water $(400 \mathrm{~mL})$ was carefully added to facilitate the settling phase. The supernatant was removed, and the remaining material was washed three times with $400 \mathrm{~mL}$ of ultrapure water. The remaining paste was separated by filtration and washed with water until neutral conditions of $\mathrm{pH}=5-6$. The obtained product was lyophilized and then dried in a vacuum oven for $24 \mathrm{~h}$ at $80^{\circ} \mathrm{C}$. Then, $5 \mathrm{~g}$ of the sample was heated at $5{ }^{\circ} \mathrm{C} \min ^{-1}$ until $750{ }^{\circ} \mathrm{C}$ under $\mathrm{H}_{2}$-Ar gases mixture $\left(10\right.$ vol. $\% \mathrm{H}_{2}$, flow rate $3 \mathrm{~L}$ $\mathrm{h}^{-1}$ ). After $4 \mathrm{~h}$, the material was cooled down to room temperature, which was finally estimated to a $70 \%$ mass yield of rGO.

\subsection{Synthesis of the nanocatalysts and TEM characterization}

The used glassware for the synthesis of the supported nanoparticles were subjected to a preliminary cleaning, which consists of a stay of about $30 \mathrm{~min}$ in a $\mathrm{HNO}_{3}-\mathrm{HCl}$ mixture (aqua regia) followed by a boiling and cold ultrapure water flushing. For the synthesis of $\mathrm{Au}_{\mathrm{x}} \mathrm{Pt} / \mathrm{rGO}$ or $\mathrm{Au}_{\mathrm{x}} \mathrm{Pt}_{\mathrm{y}} / \mathrm{Vulcan}$ ( $x$ and $y$ stand for the corresponding atomic percentages), appropriate amounts of $\mathrm{HAuCl}_{4} \cdot 3 \mathrm{H}_{2} \mathrm{O}$ and $\mathrm{H}_{2} \mathrm{PtCl}_{6} \cdot 6 \mathrm{H}_{2} \mathrm{O}$ were put in a $500 \mathrm{~mL}$ round-bottom flask and dissolved with $100 \mathrm{~mL}$ of water under stirring to prepare a solution at $1 \mathrm{mM}$ of metallic cation. This was followed by the introduction of $\mathrm{KBr}$, wherein the molar ratio $\mathrm{KBr} / \mathrm{metal}(\mathrm{s})$ was fixed to 1.46 [42]. Then, a suitable amount of carbon that corresponds to a 
final metal loading of $20 \mathrm{wt}$. \% was introduced and the mixture was put for sonication. After 45 min of impregnation, $15 \mathrm{~mL}$ of $0.1 \mathrm{M} \mathrm{NaBH}_{4}$ was introduced dropwise under vigorous stirring at room temperature. The reactor was kept in an oil bath at $40{ }^{\circ} \mathrm{C}$ under stirring. After $2 \mathrm{~h}$, the reaction was quenched by filtering over a Buchner system. The powder of the supported catalysts was finally recovered after drying in an oven at $70{ }^{\circ} \mathrm{C}$ overnight. The assynthesized catalytic nanoparticles were imaged in bright-field by transmission electron microscopy (JEOL 2100 UHR TEM, 200 kV).

\subsection{Fuel cell operation}

The catalysts were studied in a glucose $/ \mathrm{O}_{2}$ fuel cell to compare their selectivity performance at room temperature. The cell consisted of two Teflon compartments each filled with $25 \mathrm{~mL}$ of 0.1 M KOH electrolytic solution, separated by a Fumatech AEM (Fumasep FAA nonreinforced on PET paper). The anode compartment contained $50 \mathrm{mM}$ glucose. Throughout the experiment, $\mathrm{N}_{2}$ and $\mathrm{O}_{2}$ were bubbled in the anode and cathode compartments, respectively. The catalytic ink was prepared by mixing ultrasonically $4 \mathrm{mg}$ of catalyst, $300 \mu \mathrm{L}$ of water, and $25 \mu \mathrm{L}$ of Nafion ${ }^{\circledR}$ suspension. Then, the anode and the cathode were prepared by dropcasting this catalytic ink on both sides of a Toray carbon paper $\left(2 \times 0.3 \mathrm{~cm}^{2}\right)$ to reach a metal loading of $0.2 \mathrm{mg}_{\text {metal }} \mathrm{cm}^{-2}$. Small silver-silver chloride reference electrodes (BASi Reference Electrodes, RE-6 Ag/AgCl) were used to measure the potential of each electrode with a voltmeter on each side of the fuel cell.

\subsection{High-performance liquid ionic chromatography (HPLIC)}

The solutions extracted from the fuel cell operation were diluted three times with MQ water for HPLIC analysis. The latter chromatograph was a Dionex ICS 5000 model equipped with an IonPac AS15 column used in isocratic mode that utilized $10 \mathrm{mM} \mathrm{NaOH}$ solution as eluent 
at a flow rate of $0.3 \mathrm{~mL} \mathrm{m^{-1 }}$ and an injected volume of $20 \mu \mathrm{L}$. The instrument operated with a conductivity detector (CD-5000). Control electrolysis was performed by using a Pyrexbased two-compartment cell equipped with an AEM (Fumapem ${ }^{\circledR}$ FAA-3-50, Fumatech). For that, the catalytic ink was prepared by mixing $375 \mu \mathrm{L}$ water, $50 \mu \mathrm{L}$ Nafion ${ }^{\circledR}$ suspension and 4 mg of the catalyst. Then, $2 \times 50 \mu \mathrm{L}$ were deposited onto both surfaces of the Toray carbon paper $\left(2 \times 3 \mathrm{~cm}^{2}\right)$ and dried at room temperature. The collected samples from the electrolysis were analyzed by HPLIC (Dionex ICS-1000, AS19 column) and operated with KOH as eluent at $10 \mathrm{mM}$ for $10 \mathrm{~min}$ then gradient up to $45 \mathrm{mM}$ for $20 \mathrm{~min}$ and finally $10 \mathrm{mM}$ for $10 \mathrm{~min}$.

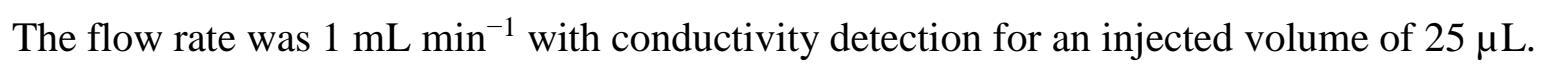

\section{6. $\quad$ Liquid chromatography coupled with mass spectrometry (LC-MS)}

The solutions extracted from the fuel cell operation were neutralized in cationic resin (DOWEX 50WX8-200, Sigma-Aldrich) and then lyophilized. The remaining solid was dissolved with $3 \mathrm{~mL}$ of water for the LC-MS analysis. The used column for LC was Aminex HPX-87H $(30 \mathrm{~cm})$ in isocratic mode. An aliquot of $5 \mu \mathrm{L}$ of the samples was injected with a diluted formic acid solution as eluent $\left(0.01 \mathrm{wt} . \%\right.$ in water) circulating at $0.6 \mathrm{~mL} \mathrm{~min}^{-1}$. The LC was equipped with a UV detector. The used MS was a Thermo Fisher Scientific linear trap LTQ XL, and was operating in a negative ionization mode. The instrument was equipped with a $300{ }^{\circ} \mathrm{C}$ electrospray ionization source powered at $2.8 \mathrm{kV}$ (quadrupole, octapole, an ion trap). The selected $\mathrm{m} / \mathrm{z}$ range was from 100 to 600 . The advantage of this device lies in the possibility of cascade fragmentation: the MS daughter ion resulting from the fragmentation of the parent molecule can be further fragmented into several MS2 fragments, and so on. This method brings an additional precision on the identification of the starting compound. On each mass spectrum, the parent ion that is fragmented to obtain the next generation is boxed. 


\section{Results and discussion}

\subsection{Physicochemical characterization}

We previously examined the electrochemical properties by cyclic voltammetry (CV), and electrocatalytic performance by the direct glucose fuel cell in alkaline medium [39]. So, the characterization was not performed herein. The present nanocatalysts (reduced graphene oxide, monometallic gold, monometallic platinum and bimetallic gold-platinum) were extensively characterized by the physicochemical methods of Raman spectroscopy, X-Ray diffraction (XRD), X-ray photoelectron spectroscopy (XPS) [39]. We provided herein the representative TEM images (Figure 1) of the materials of interest. We especially report the TEM micrographs and the particle size distributions of the materials that were synthesized as anode, Au/rGO (Figure 1a), Pt/rGO (Figure 1b), and $\mathrm{Au}_{50} \mathrm{Pt}_{50} / \mathrm{rGO}$ (Figure 1c). The Pt/Vulcan (Figure 1d) material was selected as the cathode of the fuel cell. It can be observed that Figures 1a-c highlight the presence of the rGO sheets, while Figure 1d shows the granular nature of the Vulcan substrate [43]. The quasi-spherical nanoparticles have a size of about 1.8, 8.7, 4.4, and $1.9 \mathrm{~nm}$ for $\mathrm{Pt} / \mathrm{rGO}, \mathrm{Au}_{50} \mathrm{Pt}_{50} / \mathrm{rGO}, \mathrm{Au} / \mathrm{rGO}$, and $\mathrm{Pt} / \mathrm{Vulcan}$, respectively. For $\mathrm{Au}_{50} \mathrm{Pt}_{50} / \mathrm{rGO}$, the increase of the particle size is due to the presence of small particles $(<5$ $\mathrm{nm})$, and bigger one (>10 $\mathrm{nm})$.

\subsection{Preliminary fuel cell operation}

Before performing an in-depth electroanalytical study, a typical characterization of the direct alkaline glucose fuel cell was carried out. It should be noted that the comparison of the electrical performance of the different anode materials is out of the scope of this study. Figure $2 \mathrm{a}$ shows the typical polarization curves in terms of cell voltage and power density, wherein $\mathrm{Au}_{70} \mathrm{Pt}_{30} / \mathrm{rGO}$ was used as the anode and $\mathrm{Pt} / \mathrm{Vulcan}$, as the cathode. The open circuit voltage is $\mathrm{OCV}=0.95 \mathrm{~V}$ and the maximal power density which is $P_{\max }=0.8 \mathrm{~mW} \mathrm{~cm}^{-2}$, is reached at a 
current density of $j=1.3 \mathrm{~mA} \mathrm{~cm} \mathrm{~cm}^{-2}$ with a cell voltage of $0.6 \mathrm{~V}$. Based on these initial assessments, we next implemented a galvanostatic operation to probe the ability of the glucose fuel cell to deliver a constant current density, which is the typical operation of fuel cells. Figure $2 \mathrm{~b}$ displays the $U$ vs $t$ traces of the different anode materials $(\mathrm{Au} / \mathrm{rGO}$, $\mathrm{Au}_{70} \mathrm{Pt}_{30} / \mathrm{rGO}, \mathrm{Au}_{50} \mathrm{Pt}_{50} / \mathrm{rGO}$ and $\left.\mathrm{Pt} / \mathrm{rGO}\right)$ and $\mathrm{Pt} /$ Vulcan as cathode. An intermediate current density of $\mathrm{j}=1 \mathrm{~mA} \mathrm{~cm}{ }^{-2}$ was chosen to mimic the operation of fuel cell, which is typically around $2 / 3 \times P_{\max }$. The results of Figure $2 \mathrm{~b}$ demonstrate that all anode materials maintain a significant cell voltage after $2 \mathrm{~h}$ of operation. As the amount of the reacted glucose was the same due to the galvanostatic operation, the gradual decrease can only be attributed to the stability of the anode materials. Specifically, the cell voltage of $\mathrm{Pt} / \mathrm{rGO}$ anode decreases after $2000 \mathrm{~s}$, from 0.8 to $0.5 \mathrm{~V}$ (ca. $40 \%$ loss). In the same time, Au/rGO depicts a minor loss. This explains the behavior of the bimetallic materials for which $\mathrm{Au}_{70} \mathrm{Pt}_{30} / \mathrm{rGO}$ has an $\mathrm{Au} / \mathrm{rGO}-\mathrm{like}$ profile and $\mathrm{Au}_{50} \mathrm{Pt}_{50} / \mathrm{rGO}$ follows $\mathrm{Pt} / \mathrm{rGO}$. Based of those outcomes and considering that the electroanalytical results have the same trends in terms of distribution of reaction products, only the results of the $\mathrm{Au}_{50} \mathrm{Pt}_{50} / \mathrm{rGO}$ anode material are presented in the next sections for simplicity.

\subsection{Half-cell operation in a three-electrode configuration and HPLIC analysis}

We next designed electrochemical experiments to examine closely the considered $\mathrm{Au}_{50} \mathrm{Pt}_{50} / \mathrm{rGO}$ anode material in a half-cell before its integration into a direct glucose fuel cell. To this end, a H-type cell was constructed. A Fumapem ${ }^{\circledR}$ FAA-3-50 membrane (AEM) separated the compartment of the working electrode (outgassed solution of $0.1 \mathrm{M} \mathrm{KOH}+50$ $\mathrm{mM}$ glucose, $50 \mathrm{~mL}$ ) and that of the counter electrode (outgassed solution $0.1 \mathrm{M} \mathrm{KOH}, 50$ $\mathrm{mL}$ ). Figure $3 \mathrm{a}$ shows the typical $\mathrm{CVs}$ recorded at $100 \mathrm{mV} \mathrm{s}^{-1}$ during the glucose electrooxidation, which highlights an onset potential of about $0.1 \mathrm{~V}$ vs RHE. The detailed 
discussion of the performance with the monometallic electrocatalysts and the literature is beyond the scope of the present study. It worth mentioning that our preliminary and more dedicated study (ref. 39) showed a synergy for bimetallic electrocatalysts and competitive performance compared to the existing literature. After those cycles of $\mathrm{CV}$, an aliquot of 500 $\mu \mathrm{L}$ was sampled for further HPLIC analysis. Then, a comparative investigation was done by both chronopotentiometry (CP) at $\mathrm{j}=1 \mathrm{~mA} \mathrm{~cm}^{-2}$ (as previously) and chronoamperometry (CA) at $E_{\text {appl }}=0.65 \mathrm{~V}$ vs RHE. Figure $3 \mathrm{~b}$ displays the $E$ vs $t$ trace. The continuous augmentation of the potential of the anode could be mostly attributed to the mass transport given the low diffusion coefficient of glucose in aqueous solution, $\mathrm{D}=6.9 \times 10^{-10} \mathrm{~m}^{2} \mathrm{~s}^{-1}$ [44]. This is particularly true because the designed system operated in a batch cell in which no product outlet is provided. The results of CA at $0.65 \mathrm{~V}$ vs RHE are reported in Figure 3c. To examine the evolution of the product distribution, the reaction was stopped for about $60 \mathrm{~s}$ in order to pipette about $500 \mu \mathrm{L}$ of the solution for HPLIC analysis. Such experiments allow to verify the electrochemical stability of the investigated material and its catalytic activity for a given applied potential, as recently reported for the glycerol electrooxidation in alkaline media [45]. Furthermore, this relaxation experiment is a powerful tool to probe the mass transport limitation. The findings in Figure $3 \mathrm{c}$ confirm the good stability of the bimetallic electrode that combines the activity of the platinum component and the stability of the gold one. The results also pointed out the mass transport limitation. Based on our previous reports on glucose electrocatalysis $[28,39,46]$, we hypothesized that the present rGO-supported goldbased nanoparticles would not also trigger the cleavage of the carbon-carbon bonds in the glucose molecule. Keeping this in mind, the standards resulting from the glucose oxidation $[29,46,47]$ were analyzed by HPLIC (Dionex AS19 column). Figure 3d shows the obtained chromatograms of gluconate (2-electron oxidation at the C1-position), glucuronate (4-electron oxidation at the C6-position), and glucarate (6-electron oxidation at both the C1-position, and 
the C6-position) $[29,47]$. The retention time is $4.3,6.5$, and $15.0 \mathrm{~min}$ for gluconate, glucuronate, and glucarate, respectively. Figure $3 \mathrm{e}$ gathers the HPLIC results from the samples collected after $\mathrm{CV}, \mathrm{CP}$ and $\mathrm{CA}$. For the results from $\mathrm{CA}$, the increase in the intensity of the main peaks is in agreement with the current decay in Figure 3c, which indicates that the glucose amount diminishes, while that of the products augments. The first highlight is the absence of the peak at 15 min, which means that glucarate is not a reaction product of the electrocatalytic oxidation at the present nanocatalysts. The presence of gluconate and glucuronate as the reaction products was attested by the peaks at the retention time of 4.3 , and $6.4 \mathrm{~min}$, respectively. An unexpected peak was observed at the retention time of ca. $5.0 \mathrm{~min}$. It was previously postulated that the pair of peaks at 4.3 and 5.0 min belong to gluconate [28]. Furthermore, the oxidation of the primary alcohol at the C6-position leading to glucuronate instead of the carbonyl function at the C1-position suggests that the present rGO-supported metallic nanoparticles promote the selective oxidation at the terminal carbon atoms. This set of results substantiate the previous observation about the glucose reactivity via the anomeric carbon at the $\mathrm{C} 1$-position and simultaneously provide new insights on the reactivity of the glucose molecule through the C6-position. However, these results obtained during the halfcell operation may differ from those that could be obtained for a fuel cell operation. To probe such a scenario, we then electroanalytically studied the reaction in a direct alkaline fuel cell.

\subsection{Direct alkaline fuel cell operation in a two-electrode configuration and HPLIC analysis}

The above discussion only demonstrates the reactivity of glucose, in a traditional threeelectrode cell, through both the anomeric carbon (C1-position) and the primary alcohol (C6position) at the surface of $\mathrm{Au}_{50} \mathrm{Pt}_{50} / \mathrm{rGO}$ anode material, which was also true at other goldplatinum/rGO materials. The debate for the electrochemists engaged in cogeneration fuel cells 
is whether such selectivity can be maintained or not in power generation mode. This was the case for glycerol once it was integrated into a fuel cell device $[48,49]$. So, this would a priori be true for glucose, but it needs to be verified experimentally. We then developed a specific study for this purpose. During the galvanostatic operation of the direct alkaline fuel cell at $\mathrm{j}=$ $1 \mathrm{~mA} \mathrm{~cm}{ }^{-2}$, the potentials of the anode and cathode were recorded (Figure 4a). For a given cell voltage (Figure 4b), few microliters were taken sequentially from the anode compartment and immediately analyzed by HPLIC (Figure 4c). The curves of the potential versus time for the anode and cathode, Figure 4a, assume that the fuel cell performance is mostly limited by the reaction taking place at the anode. Such results can be explained by a reduced electrochemical kinetics of the glucose oxidation reaction at the anode in comparison to the oxygen reduction reaction that occurs at the cathode. Another possible explanation is the configuration of the fuel cell, which was operating under batch conditions without a regular removal of the reaction products from electrodes and the refueling by new reactant. Figure $4 \mathrm{c}$ displays the chromatograms of the samples separated on a IonPac AS15 column. They correspond to three peaks referred to as $\mathrm{A}, \mathrm{B}$ and $\mathrm{C}$ at the retention time of 4.6, 5.2, and 8.8 min, respectively. For a better assignment, we performed control experiments shown in Figure $4 \mathrm{~d}$ to unambiguously attribute the peaks to the corresponding products. It can be concluded that the peak $\mathrm{C}$ belongs to glucuronate, while peaks $\mathrm{A}$ and $\mathrm{B}$ with close retention times (meaning that they have similar ionic conductivity) could be assigned to the same product, for instance gluconate. Figure $4 \mathrm{~d}$ shows that the un-ionized glucose is quickly eluted, with almost no interaction with the stationary phase of the column. The presence of the doublet A and B when gluconate + glucose mixture was injected would suggest a possible interference of the unreacted glucose since the peak B appears only when glucose was added. This interference, however, does not affect the area of the peak A as displayed in Figure 4d, which means that only the area of that peak A should be considered for later quantification from the 
chromatograms reported in Figure 4c. Figure 4d shows that the used column (IonPac AS15) for this part of the study does not allow a precise detection of the glucaric acid. So, only the LC-MS investigation will enable to determine whether a 6-electron product is possible or not at the present materials.

Based on the calibration curves of the reference compounds, the linear relationship between the area of the peak $(y)$ and the corresponding molar concentration $(x)$ is $y=9.9 x+$ $1.7\left(R^{2}=0.997\right)$, and $y=16.6 x+6.3\left(R^{2}=0.996\right)$ for gluconate and glucuronate, respectively. From the chromatograms shown in Figure 4c (a $300 \mu \mathrm{L}$ anodic solution was collected and diluted by adding $600 \mu \mathrm{L}$ MQ water, and immediately injected), the sample collected at 2 min indicates the presence of a peak at a retention time of $5.2 \mathrm{~min}$ accompanied with a shoulder around $4.7 \mathrm{~min}$. Based on the previous control experiments, those observations were assigned to the mixture of gluconate and glucose. The area of the invariant peak at $8.8 \mathrm{~min}$ corresponding to glucuronate could indicate that the electrooxidation at the C6-position still occurs during the fuel cell operation. The comparison of the chromatograms from the operation in a 3-electrode reactor (Figure 3e), and the 2-electrode fuel cell (Figure 4c), indicates that there is a drastic change about the reactivity of the primary alcohol function. Figure $4 \mathrm{e}$ shows the evolution of different concentrations of the products. This figure also displays the theoretical total concentration of the product(s) from three possible scenarios of an exchange number of electrons, $n_{\mathrm{ex}}=2$ (gluconate), 4 (glucuronate) and 3 (gluconate + glucuronate), evaluated with Eq. 1.

$$
c=\frac{Q}{n_{e x} V F}=\frac{\int I d t}{n_{e x} V F}=\frac{I t}{n_{e x} V F}
$$

where $I(\mathrm{~mA})$ is the current intensity, $t(\mathrm{~s})$ is the time, $n$ is the number of electrons exchanged in the reaction, $V(\mathrm{~L})$ the volume of anodic solution and $\mathrm{F}\left(=96485 \mathrm{C} \mathrm{mol}^{-1}\right)$ the Faraday constant. 
It can be observed from Figure $4 \mathrm{e}$ that glucuronate as a minor product was predominantly produced at the very beginning of the fuel cell operation, when the cell voltage is high and so the anode potential is low. After $\sim 10 \mathrm{~min}$, the produced gluconate and glucuronate amounts are almost the same. The quantitative analysis shows that the major product is gluconate. Its concentration reaches $0.56 \mathrm{mM}$ after $2 \mathrm{~h}$, which represents about $90 \%$ of selectivity towards the total products (gluconate + glucuronate). The estimated Faradaic efficiency is $65 \%$ when considering the theoretical value from a two-electron reaction. For glucuronate, the selectivity towards a 4-electron pathway is $10 \%$. The profile of the total concentration follows the trend of the theoretical 3-electron pathways, which is in line with the presence of both gluconate $\left(n_{\mathrm{ex}}=2\right)$ and glucuronate $\left(n_{\mathrm{ex}}=4\right)$ so that the real-transfer number of electrons is between 2 and 4. The deviation at the beginning of the experiment $(t \leq 20 \mathrm{~min})$ is attributed to the confidence in the calibration curve in this range. For higher duration $(t \geq 20 \mathrm{~min})$, it is likely that glucarate is a reaction product because glucuronate can easily react via its carbon at the C1-position into a 2-electron process leading to an overall 6-electron transfer process. This scenario will be further verified by the LC-MS study. According to the findings from HPLIC on the course of the fuel cell operation, Figure $4 \mathrm{f}$ sketches the scheme of the electrocatalytic oxidation of glucose. For the scheme, we utilized the main predominant form of glucose in aqueous media i.e glucopyranose at $99 \%$ (the remaining is $0.5 \%$ linear, and $0.5 \%$ glucofuranose). The adsorption via the C1-position leads to gluconate, while glucuronate results from an initial adsorption through the C6-position.

\subsection{Direct alkaline fuel cell operation in a two-electrode configuration and LC-MS} analysis

To gain further insight into the nature of the reaction products resulting from the fuel cell operation, we next performed LC-MS study. Before the analysis of the real sample, the 
previous standards were also used as references in LC-MS. Given the low pKa of those weak acids (gluconic, glucuronic, and glucaric [50]), the chosen eluent was composed of water and formic acid at $0.01 \mathrm{wt} . \%$ with a flow rate of $0.6 \mathrm{~mL} \mathrm{~min}^{-1}$. Hence, glucose, gluconic acid, glucuronic acid, and glucaric acid can be easily investigated. The obtained chromatograms of the four compounds, and their retention times are shown in Figure 5. The retention time follows the acidity strength in the order: glucaric acid (retention time $=6.8 \mathrm{~min}$ ) $>$ glucuronic acid $($ retention time $=6.9 \mathrm{~min})>$ gluconic acid $($ retention time $=8.0 \mathrm{~min})>$ glucose $($ retention time $=8.4 \mathrm{~min})$. It results that $\mathrm{LC}$ does not allow making a significant difference between glucaric, and glucuronic acids. However, the atomic mass in MS configuration should allow a precise distinction.

The spectra obtained from the MS analysis in negative-ionization mode (M-1) are shown in Figures 6a-d. The MS spectrum presented in Figure 6c shows that the most abundant fragment, associated with the glucose retention time of 8.4 min (Figure 5c), corresponds to the ratio $m / z=225$, while the fragment of pseudo-molecular ion at $\mathrm{m} / \mathrm{z}=179$ (M(glucose) - 1) has a relative abundance of only $20 \%$. At the MS2 generation resulting from the fragmentation of the $m / z=225$ ion, the $m / z=179$ fragment corresponding to deprotonated glucose becomes predominant. From this, it is deduced that the fragment $\mathrm{m} / \mathrm{z}=225$ corresponds to the association of glucose and deprotonated formic acid: M(glucose) + $\mathrm{M}(\mathrm{HCOOH})-1=180+46-1=225$. The MS spectrum of gluconic acid in Figure 6a shows a peak of high intensity at $m / z=195$, which corresponds exactly to deprotonated gluconic acid. The MS spectra of glucuronic acid (Figure 6b) and glucaric acid (Figure 6d) show, similarly, major fragments at $m / z=209$, and 193. For glucaric acid, these peaks correspond respectively to the parent ion and a loss of an $\mathrm{O}$ atom during the fragmentation. For glucuronic acid, the $m / z=193$ fragment corresponds to the parent ion. The peak of $m / z=209$ may indicate an association of the acid with an $\mathrm{O}$ atom or a $\mathrm{CH}_{4}$ group from another 
fragmentation. The difference between these two acids appears clearly on the MS2 spectra: the fragmentation of glucuronic acid gives a multitude of fragments, while glucaric acid leads mainly to $m / z=191$.

Figure $7 \mathrm{a}$ shows the raw chromatogram of the neutralized solution following the oxidation of glucose. The same profile of LC was obtained for the other synthesized and tested catalysts. Thus, the interpretation of the results can be generalized. The compound detected at the retention time of 8.43 min was identified as glucose by comparison with the retention time of the standards (Figure 6c). By the same method, the peak at the retention time of $7.92 \mathrm{~min}$ was associated with gluconic acid, and the peak at the retention time of $6.90 \mathrm{~min}$ can correspond to either glucuronic acid or glucaric acid. However, the two peaks at the retention time of 9.19 , and 9.85 min have not yet been identified clearly. By isolating the chromatograms of the compound corresponding to the fragments detected at $m / z=225$ and 179, i.e. glucose, a doubling of the chromatographic peak appears. The MS, MS2 and MS3 mass spectra of the first peak detected at the retention time of $8.43 \mathrm{~min}$ (Figure $7 \mathrm{~b}$ ) are very similar to the mass spectra of the glucose standard. The MS mass spectrum of the second peak at the retention time of $9.19 \mathrm{~min}$ (Figure 7c) is very similar to the MS spectrum of the previous peak, but this is not the case for the MS2 spectrum. However, the MS3 and MS4 spectra in Figure $7 \mathrm{~b}$ are almost identical to the MS2 and MS3 spectra in Figure 7c, respectively. So, the latter have a structure very close to glucose. It can be presumably galactose, an epimeric form of glucose in which the $\mathrm{OH}$ group of $\mathrm{C}_{4}$ is in an axial position, which could have been formed in a $\mathrm{KOH}$ medium.

Figure 8 shows the MS and MS2 mass spectra associated with LC peaks detected at the retention time of $6.90 \mathrm{~min}$ (Figure 8a), $7.92 \mathrm{~min}$ (Figure 8b) and $9.85 \mathrm{~min}$ (Figure 8c). Figure $8 \mathrm{~b}$ shows that the compound detected at the retention time of 7.92 min induces a main peak at $m / z=195$ in MS, which corresponds to the pseudo-molecular ion $[\mathrm{M}-\mathrm{H}]^{-}$of gluconic 
acid in agreement with the results of Figures 5a and 6a. The MS and MS2 spectra (Figure 8a) associated with the LC peak at the retention time of $6.90 \mathrm{~min}$ correspond to the spectra of the glucaric acid that has a pseudo-molecular ion $[\mathrm{M}-\mathrm{H}]^{-}$of $\mathrm{m} / \mathrm{z}=209$, which is in agreement with the commercial sample (Figure 6d). The finding finally confirmed our previous hypothesis that an initial oxidation of the glucose via its carbon at the C6-position triggers a further oxidation at the C1-position, which leads to a total transferred number of electrons of $n_{\mathrm{ex}}=4+2=6$. Figure $8 \mathrm{c}$ indicates that the LC peak at the retention time of $9.85 \mathrm{~min}$ has a main MS peak situated at $m / z=193$, which is associated with the pseudo-molecular ion [M$\mathrm{H}]^{-}$of glucuronic acid. However, the MS2 spectrum is different from that obtained with the standard (Figure 6b). Although no quantification has been performed, glucaric acid has been detected in trace amounts. The sensitivity of the glucaric acid detection is 60 times lower than glucuronic acid, and 200 times lower than for gluconic acid. Those electroanalytical investigations have allowed to elucidate unambiguously the nature of the reaction products resulting from the operation of the direct alkaline glucose fuel cell. The products distribution is identical between a conventional three-electrode configuration and the energy conversion setup of a fuel cell.

\section{Conclusion}

There is currently a great challenge of developing model methodologies for the future study

of the cellulosic biomass electro-reforming. By electroanalytical methods, we report herein the selective electrooxidation of the cellulosic biomass-derived glucose at reduced graphene oxide supported gold-based nanocatalysts in an anion exchange membrane fuel cell. The catalytic AuPt nanoparticles of 3-5 nm were prepared through a simple organic capping agent and surfactant-free method, referred to as the bromide anion exchange method. The precise study of the glucose electrooxidation reaction firstly in half-cell and secondly in a direct 
alkaline fuel cell was performed by integrating electroanalytical methods of cyclic voltammetry $(\mathrm{CV})$, chronoamperometry $(\mathrm{CA})$, chronopotentiometry $(\mathrm{CP})$, high-performance liquid ion chromatography (HPLIC), and liquid chromatography coupled with mass spectrometry (LC-MS). These complementary methods permitted to unambiguously identify the products resulting from the electrooxidation of this oligosaccharide in alkaline media. Gluconate was found to be the main product of a two-electron glucose oxidation process with a selectivity of $90 \%$ (Faradaic efficiency of 65\%). In addition, these methods also demonstrated the presence of glucuronate as a four-electron oxidation product. Glucarate as a trace product was determined by the LC-MS. In other words, no product that would be the consequence of a carbon-carbon bond cleavage was observed. This is a good starting point on the road to $\mathrm{CO}_{2}$-free processes from the biomass electro-reforming. The present findings of particular importance open new possibilities of targeting the use of raw cellulose in fuel cell reactors for the simultaneous production of electricity and chemicals of high interest.

\section{Acknowledgments}

This work was financially supported by the financial support by the French National Research Agency (ANR, the project IMABIC), the European Union (ERDF) and "Région NouvelleAquitaine". The authors are grateful to Valerie Bonniol (IEM Montpellier) for assistance during HPLIC (Dionex ICS-1000, AS19 column) analysis. The authors have no competing interests to declare.

\section{References}

[1] A.T. Yahiro, S.M. Lee, D.O. Kimble, Bioelectrochemistry: I. Enzyme utilizing bio-fuel cell studies, Biochim. Biophys. Acta 88 (1964) 375-383. https://doi.org/10.1016/09266577(64)90192-5. 
[2] R.M. Allen, H.P. Bennetto, Microbial fuel-cells, Appl. Biochem. Biotechnol. 39 (1993) 27-40. https://doi.org/10.1007/bf02918975.

[3] E. Katz, K. MacVittie, Implanted biofuel cells operating in vivo - methods, applications and perspectives - feature article, Energy Environ. Sci. 6 (2013) 2791-2803. https://doi.org/10.1039/c3ee42126k.

[4] E. Katz, I. Willner, A.B. Kotlyar, A non-compartmentalized glucose $/ \mathrm{O}_{2}$ biofuel cell by bioengineered electrode surfaces, J. Electroanal. Chem. 479 (1999) 64-68. https://doi.org/10.1016/s0022-0728(99)00425-8.

[5] S.C. Barton, J. Gallaway, P. Atanassov, Enzymatic biofuel cells for implantable and microscale devices, Chem. Rev. 104 (2004) 4867-4886. https://doi.org/10.1021/cr020719k.

[6] G.A. Justin, Y. Zhang, S. Mingui, R. Sclabassi, Biofuel cells: a possible power source for implantable electronic devices, Conference proceedings of the $26^{\text {th }}$ Annual International Conference of the IEEE Engineering in Medicine and Biology Society, IEEE Conference Publications, San Francisco, $\quad$ CA, 2004, pp. 4096-4099. https://doi.org/10.1109/NEBC.2004.1299985.

[7] P. Cinquin, S. Cosnier, N. Belgacem, M.L. Cosnier, R. Dal Molin, D.K. Martin, Implantable glucose biofuel cells for medical devices, J. Phys.: Conf. Ser. 476, Iop Publishing Ltd, Bristol, 2013, 012063. https://doi.org/10.1088/1742-6596/476/1/012063.

[8] Y. Chung, D.C. Tannia, Y. Kwon, Glucose biofuel cells using bi-enzyme catalysts including glucose oxidase, horseradish peroxidase and terephthalaldehyde crosslinker, Chem. Eng. J. 334 (2018) 1085-1092. https://doi.org/10.1016/j.cej.2017.10.121.

[9] B.-D. Hong, C.-L. Lee, Specific activities of rhombic dodecahedral, octahedral, and cubic $\mathrm{Cu}_{2} \mathrm{O}$ nanocrystals as glucose oxidation catalysts, Chem. Eng. J. 382 (2020) 122994. https://doi.org/10.1016/j.cej.2019.122994. 
[10] P. Lv, H. Zhou, A. Mensah, Q. Feng, D. Wang, X. Hu, Y. Cai, L. Amerigo Lucia, D. Li, Q. Wei, A highly flexible self-powered biosensor for glucose detection by epitaxial deposition of gold nanoparticles on conductive bacterial cellulose, Chem. Eng. J. 351 (2018) 177-188. https://doi.org/10.1016/j.cej.2018.06.098.

[11] Ó. Santiago, E. Navarro, M.A. Raso, T.J. Leo, Review of implantable and external abiotically catalysed glucose fuel cells and the differences between their membranes and catalysts, Appl. Energy 179 (2016) 497-522. https://doi.org/10.1016/j.apenergy.2016.06.136.

[12] A. Zebda, J.-P. Alcaraz, P. Vadgama, S. Shleev, S.D. Minteer, F. Boucher, P. Cinquin, D.K. Martin, Challenges for successful implantation of biofuel cells, Bioelectrochem. 124 (2018) 57-72. https://doi.org/10.1016/j.bioelechem.2018.05.011.

[13] S. Hebié, T.W. Napporn, C. Morais, K.B. Kokoh, Size-dependent electrocatalytic activity of free gold nanoparticles for the glucose oxidation reaction, ChemPhysChem 17 (2016) 1454-1462. https://doi.org/10.1002/cphc.201600065.

[14] C. Megias-Sayago, J.L. Santos, F. Ammari, M. Chenouf, S. Ivanova, M.A. Centeno, J.A. Odriozola, Influence of gold particle size in Au/C catalysts for base-free oxidation of glucose, Catal. Today 306 (2018) 183-190. https://doi.org/10.1016/j.cattod.2017.01.007.

[15] Y.B. Vassilyev, O.A. Khazova, N.N. Nikolaeva, Kinetics and mechanism of glucose electrooxidation on different electrode-catalysts: Part I. Adsorption and oxidation on platinum, J. Electroanal. Chem. Interfacial Electrochem. 196 (1985) 105-125. https://doi.org/10.1016/0022-0728(85)85084-1.

[16] D. Basu, S. Basu, Synthesis and characterization of Pt-Au/C catalyst for glucose electrooxidation for the application in direct glucose fuel cell, Int. J. Hydrogen Energy 36 (2011) 14923-14929. https://doi.org/10.1016/j.ijhydene.2011.03.042. 
[17] A. Habrioux, E. Sibert, K. Servat, W. Vogel, K.B. Kokoh, N. Alonso-Vante, Activity of platinum-gold alloys for glucose electrooxidation in biofuel cells, J. Phys. Chem. B 111 (2007) 10329-10333. https://doi.org/10.1021/jp0720183.

[18] J.-S. Ye, Z.-T. Liu, C.-C. Lai, C.-T. Lo, C.-L. Lee, Diameter effect of electrospun carbon fiber support for the catalysis of Pt nanoparticles in glucose oxidation, Chem. Eng. J. 283 (2016) 304-312. https://doi.org/10.1016/j.cej.2015.07.071.

[19] L. Yan, X. Qi, Degradation of Cellulose to Organic Acids in its Homogeneous Alkaline Aqueous Solution, ACS Sustain. Chem. Eng. 2 (2014) 897-901. https://doi.org/10.1021/sc400507s.

[20] Y. Sugano, N. Kumar, M. Peurla, J. Roine, A. Aho, J. Bobacka, J.-P. Mikkola, Specific electrocatalytic oxidation of cellulose at carbon electrodes modified by gold nanoparticles, ChemCatChem 8 (2016) 2401-2405. https://doi.org/10.1002/cctc.201600190.

[21] M. Hao, X. Liu, M. Feng, P. Zhang, G. Wang, Generating power from cellulose in an alkaline fuel cell enhanced by methyl viologen as an electron-transfer catalyst, J. Power Sources 251 (2014) 222-228. https://doi.org/10.1016/j.jpowsour.2013.11.013.

[22] X. Zhao, W. Liu, Y. Deng, J.Y. Zhu, Low-temperature microbial and direct conversion of lignocellulosic biomass to electricity: Advances and challenges, Renew. Sustain. Energy Rev. 71 (2017) 268-282. https://doi.org/10.1016/j.rser.2016.12.055.

[23] S. Ramachandran, P. Fontanille, A. Pandey, C. Larroche, Gluconic acid: properties, applications and microbial production, Food Technol. Biotechnol. 44 (2006) 185-195.

[24] A. Abbadi, H. Vanbekkum, Effect of $\mathrm{pH}$ in the Pt-catalyzed oxidation of D-glucose to Dgluconic acid, J. Mol. Catal. A: Chem. 97 (1995) 111-118. https://doi.org/10.1016/13811169(94)00078-6.

[25] B. Beden, F. Largeaud, K.B. Kokoh, C. Lamy, Fourier transform infrared reflectance spectroscopic investigation of the electrocatalytic oxidation of D-glucose: Identification of 
reactive intermediates and reaction products, Electrochim. Acta 41 (1996) 701-709. https://doi.org/10.1016/0013-4686(95)00359-2.

[26] F. Largeaud, K.B. Kokoh, B. Beden, C. Lamy, On the electrochemical reactivity of anomers: electrocatalytic oxidation of $\alpha$ - and $\beta$-D-glucose on platinum electrodes in acid and basic media, J. Electroanal. Chem. 397 (1995) 261-269. https://doi.org/10.1016/00220728(95)04139-8.

[27] M. Pasta, R. Ruffo, E. Falletta, C.M. Mari, C.D. Pina, Alkaline glucose oxidation on nanostructured gold electrodes, Gold Bull. 43 (2010) 57-64. https://doi.org/10.1007/bf03214967.

[28] Y. Holade, K. Servat, T.W. Napporn, C. Morais, J.-M. Berjeaud, K.B. Kokoh, Highly Selective oxidation of carbohydrates in an efficient electrochemical energy converter: Cogenerating organic electrosynthesis, ChemSusChem 9 (2016) 252-263. https://doi.org/10.1002/cssc.201501593.

[29] R. Wojcieszak, I.M. Cuccovia, M.A. Silva, L.M. Rossi, Selective oxidation of glucose to glucuronic acid by cesium-promoted gold nanoparticle catalyst, J. Mol. Catal. A: Chem. 422 (2016) 35-42. https://doi.org/10.1016/j.molcata.2016.02.008.

[30] K.B. Kokoh, J.M. Léger, B. Beden, H. Huser, C. Lamy, "On line” chromatographic analysis of the products resulting from the electrocatalytic oxidation of D-glucose on pure and adatoms modified Pt and Au electrodes-Part II. Alkaline medium, Electrochim. Acta 37 (1992) 1909-1918. https://doi.org/10.1016/0013-4686(92)87102-6.

[31] A.S. Bandarenka, M.T.M. Koper, Structural and electronic effects in heterogeneous electrocatalysis: Toward a rational design of electrocatalysts, J. Catal. 308 (2013) 11-24. https://doi.org/10.1016/j.jcat.2013.05.006.

[32] J.W. Ma, A. Habrioux, Y. Luo, G. Ramos-Sanchez, L. Calvillo, G. Granozzi, P.B. Balbuena, N. Alonso-Vante, Electronic interaction between platinum nanoparticles and 
nitrogen-doped reduced graphene oxide: effect on the oxygen reduction reaction, J. Mater. Chem. A 3 (2015) 11891-11904. https://doi.org/10.1039/c5ta01285f.

[33] S. Navalon, A. Dhakshinamoorthy, M. Alvaro, H. Garcia, Metal nanoparticles supported on two-dimensional graphenes as heterogeneous catalysts, Coord. Chem. Rev. 312 (2016) 99148. https://doi.org/10.1016/j.ccr.2015.12.005.

[34] S. Zoladek, I.A. Rutkowska, M. Blicharska, K. Miecznikowski, W. Ozimek, J. Orlowska, E. Negro, V. Di Noto, P.J. Kulesza, Evaluation of reduced-graphene-oxide-supported gold nanoparticles as catalytic system for electroreduction of oxygen in alkaline electrolyte, Electrochim. Acta, 233 (2017) 113-122. https://doi.org/10.1016/j.electacta.2017.03.002.

[35] S. Ghosh, Y. Holade, H. Remita, K. Servat, P. Beaunier, A. Hagège, K.B. Kokoh, T.W. Napporn, One-pot synthesis of reduced graphene oxide supported gold-based nanomaterials as robust nanocatalysts for glucose electrooxidation, Electrochim. Acta 212 (2016) 864-875. https://doi.org/10.1016/j.electacta.2016.06.169.

[36] C. Wang, D. Astruc, Recent developments of metallic nanoparticle-graphene $\begin{array}{llllll}\text { nanocatalysts, } & \text { Prog. } & \text { Mater } & \text { Sci. } & 94 & \text { (2018) 306-383. }\end{array}$ https://doi.org/10.1016/j.pmatsci.2018.01.003.

[37] P. Tonda-Mikiela, T.W. Napporn, C. Morais, K. Servat, A. Chen, K.B. Kokoh, Synthesis of Gold-platinum nanomaterials using bromide anion exchange-synergistic electroactivity toward CO and glucose oxidation, J Electrochem Soc 159 (2012) H828-H833. https://doi.org/10.1149/2.001211jes.

[38] A. Caglar, D. Düzenli, I. Onal, I. Tezsevin, O. Sahin, H. Kivrak, A comparative experimental and density functional study of glucose adsorption and electrooxidation on the Au-graphene and Pt-graphene electrodes, Int. J. Hydrogen Energy 45 (2020) 490-500. https://doi.org/doi: 10.1016/j.ijhydene.2019.10.163. 
[39] C. Lemoine, L. Dubois, T.W. Napporn, K. Servat, K.B. Kokoh, Electrochemical energy conversion from direct oxidation of glucose on active electrode materials, Electrocatalysis 11 (2020) 170-179. https://doi.org/10.1007/s12678-019-00570-1.

[40] D. Xu, M.B. Stevens, M.R. Cosby, S.Z. Oener, A.M. Smith, L.J. Enman, K.E. Ayers, C.B. Capuano, J.N. Renner, N. Danilovic, Y. Li, H. Wang, Q. Zhang, S.W. Boettcher, Earthabundant oxygen electrocatalysts for alkaline anion-exchange-membrane water electrolysis: Effects of catalyst conductivity and comparison with performance in three-electrode cells, ACS Catal. 9 (2019) 7-15. https://doi.org/10.1021/acscatal.8b04001.

[41] Y. Holade, C. Morais, K. Servat, T.W. Napporn, K.B. Kokoh, Enhancing the available specific surface area of carbon supports to boost the electroactivity of nanostructured $\mathrm{Pt}$ catalysts, Phys. Chem. Chem. Phys. $16 \quad$ (2014) 25609-25620. https://doi.org/10.1039/C4CP03851G.

[42] Y. Holade, K. Servat, T.W. Napporn, K.B. Kokoh, Electrocatalytic properties of nanomaterials synthesized from "Bromide Anion Exchange" method - Investigations of glucose and glycerol oxidation, Electrochim. Acta $162 \quad$ (2015) 205-214. https://doi.org/10.1016/j.electacta.2014.11.072.

[43] Y. Holade, C. Canaff, S. Poulin, T.W. Napporn, K. Servat, K.B. Kokoh, High impact of the reducing agent on palladium nanomaterials: new insights from X-ray photoelectron spectroscopy and oxygen reduction reaction, RSC Adv. 6 (2016) 12627-12637. https://doi.org/10.1039/C5RA24829A.

[44] D. Basu, S. Basu, Synthesis, characterization and application of platinum based bimetallic catalysts for direct glucose alkaline fuel cell, Electrochim. Acta 56 (2011) 61066113. https://doi.org/10.1016/j.electacta.2011.04.072.

[45] R.G. Da Silva, S. Aquino Neto, K.B. Kokoh, A.R. De Andrade, Electroconversion of glycerol in alkaline medium: From generation of energy to formation of value-added 
products, J. Power

Sources

https://doi.org/10.1016/j.jpowsour.2017.03.101.

[46] Y. Holade, A.B. Engel, K. Servat, T.W. Napporn, C. Morais, S. Tingry, D. Cornu, K.B. Kokoh, Electrocatalytic and electroanalytic investigation of carbohydrates oxidation on goldbased nanocatalysts in alkaline and neutral pHs, J. Electrochem. Soc. 165 (2018) H425-H436. https://doi.org/10.1149/2.0311809jes.

[47] R.D. Armstrong, J. Hirayama, D.W. Knight, G.J. Hutchings, Quantitative determination of Pt- catalyzed D-glucose oxidation products using 2D NMR, ACS Catal. 9 (2019) 325-335. https://doi.org/10.1021/acscatal.8b03838.

[48] J. Qi, N. Benipal, C. Liang, W. Li, PdAg/CNT catalyzed alcohol oxidation reaction for high-performance anion exchange membrane direct alcohol fuel cell (alcohol = methanol, ethanol, ethylene glycol and glycerol), Appl. Catal. B: Environ. 199 (2016) 494-503. https://doi.org/10.1016/j.apcatb.2016.06.055.

[49] L. Xin, Z. Zhang, Z. Wang, W. Li, Simultaneous generation of mesoxalic acid and electricity from glycerol on a gold anode catalyst in anion-exchange membrane fuel cells, ChemCatChem 4 (2012) 1105-1114. https://doi.org/10.1002/cctc.201200017.

[50] P. M. Collins, Dictionary of carbohydrates, second ed., Chapman \& Hall/CRC, Taylor \& Francis Group, Boca Raton, London, New York, 2006. https://doi.org/10.2478/s11696-0060030-z. 


\section{Figures Captions:}

Fig. 1. TEM micrographs associated with respective particle size distributions of (a) $\mathrm{Au} / \mathrm{rGO}$, (b) $\mathrm{Pt} / \mathrm{rGO}$, (c) $\mathrm{Au}_{50} \mathrm{Pt} \mathrm{t}_{50} / \mathrm{rGO}$, and (d) Pt/Vulcan.

Fig. 2. (a) Fuel cell polarization curves in terms of the cell voltage (left y-axis) and power density (right $\mathrm{y}$-axis) of the $\mathrm{Au}_{70} \mathrm{Pt}_{30} / \mathrm{rGO}$ as anode and $\mathrm{Pt} / \mathrm{Vulcan}$ as cathode. (b) Evolution of cell voltage at $j=1 \mathrm{~mA} \mathrm{~cm}{ }^{-2}$ with different anode materials $\left(\mathrm{Au} / \mathrm{rGO}, \mathrm{Au}_{70} \mathrm{Pt}_{30} / \mathrm{rGO}\right.$, $\mathrm{Au}_{50} \mathrm{Pt}_{50} / \mathrm{rGO}$ and $\left.\mathrm{Pt} / \mathrm{rGO}\right)$ and $\mathrm{Pt} / \mathrm{Vulcan}$ as cathode. Electrode surface $=0.6 \mathrm{~cm}^{2}$; metal loading $=0.2 \mathrm{mg}_{\text {metal }} \mathrm{cm}^{-2} ;$ membrane $=$ Fumatech $\mathrm{AEM} ;$ anode $=0.1 \mathrm{M} \mathrm{KOH}+50 \mathrm{mM}$ glucose; cathode $=0.1 \mathrm{M} \mathrm{KOH}+\mathrm{O}_{2}$ bubbling.

\section{COLOR REQUIRED}

Fig. 3. Half-cell electrolysis in H-type reactor (working electrode $=\mathrm{Au}_{50} \mathrm{Pt}_{50} / \mathrm{rGO}\left(0.2 \mathrm{mg}_{\mathrm{metal}}\right.$ $\left.\mathrm{cm}^{-2}\right) ;$ membrane $=$ Fumapem $^{\circledR}$ FAA-3-50 $(\mathrm{AEM}) ;$ electrolyte $=0.1 \mathrm{M} \mathrm{KOH}$, glucose $=50$ $\mathrm{mM}$ ). (a) $\mathrm{CVs}$ of $\mathrm{Au}_{50} \mathrm{Pt}_{50} / \mathrm{rGO}$ (red) recorded at $100 \mathrm{mV} \mathrm{s}^{-1}$. (b) $\mathrm{CP}$ recorded at $j=1 \mathrm{~mA}$ $\mathrm{cm}^{-2}$. (c) $\mathrm{CA}$ at $0.65 \mathrm{~V}$ vs RHE. (d, e) HPLIC (eluent $=10 \mathrm{mM} \mathrm{NaOH}$; flow rate $=1 \mathrm{~mL}$ $\min ^{-1}$; column = Dionex AS19): (d) standards at $5 \mathrm{mM}$, (e) Sampled solutions from panels (b, c) $(\mathrm{dx}=$ dilution factor $)$.

\section{COLOR REQUIRED}

Fig. 4. (a, b) Evolution over time of the anode and cathode potentials (a) and cell voltage (b) during the galvanostatic operation of the DGFC at $j=1 \mathrm{~mA} \mathrm{~cm}{ }^{-2}$ (anode $=\mathrm{Au}_{50} \mathrm{Pt}_{50} / \mathrm{rGO}(0.2$ $\left.\mathrm{mg}_{\text {metal }} \mathrm{cm}^{-2}\right) ;$ cathode $=\mathrm{Pt} /$ Vulcan $\left(0.2 \mathrm{mg}_{\text {metal }} \mathrm{cm}^{-2}\right) ;$ membrane $=$ Fumatech AEM; anode $=$ 
$0.1 \mathrm{M} \mathrm{KOH}+50 \mathrm{mM}$ glucose; and cathode $=0.1 \mathrm{M} \mathrm{KOH}+\mathrm{O}_{2}$ bubbling). (c) HPLIC of the sampled solutions from panel (b): the solution was diluted three times before injection, the eluent was $10 \mathrm{mM} \mathrm{NaOH}$, the flow rate was $0.3 \mathrm{~mL} \mathrm{~min}^{-1}$ and the column was IonPac AS15. (d) HPLIC of standards at $10 \mathrm{mM}$, except glucarate $(2 \mathrm{mM})$. (e) Evolution of products concentration and theoretical concentration. (f) Scheme of the glucose electrooxidation.

\section{COLOR REQUIRED}

Fig. 5. LC of the reference (10 mM): (a) gluconic acid, (b) glucuronic acid, (c) glucose, and (d) glucaric acid. The eluent was water + formic acid $(0.01 \mathrm{wt} . \%)$, the flow rate was $0.6 \mathrm{~mL}$ $\min ^{-1}$, and the column was Aminex HPX-87H.

Fig. 6. LC-MS negative ionization mass spectra (M-1) of: (a) gluconic acid, (b) glucuronic acid, (c) glucose, and (d) glucaric acid. Red-boxed ion is fragmented to create MS2 generation.

Fig. 7. LC-MS results of the galvanostatic operation of the DGFC at $j=1 \mathrm{~mA} \mathrm{~cm}{ }^{-2}$ for 2 hours $\left(\right.$ anode $=\mathrm{Au}_{50} \mathrm{Pt}_{50} / \mathrm{rGO}\left(0.2 \mathrm{mg}_{\text {metal }} \mathrm{cm}^{-2}\right) ;$ cathode $=\mathrm{Pt} / \mathrm{Vulcan}\left(0.2 \mathrm{mg}_{\text {metal }} \mathrm{cm}^{-2}\right)$; membrane $=$ Fumatech AEM $;$ anode $=0.1 \mathrm{M} \mathrm{KOH}+50 \mathrm{mM}$ glucose $;$ and cathode $=0.1 \mathrm{M}$ $\mathrm{KOH}+\mathrm{O}_{2}$ bubbling). (a) LC of the sample after neutralization and lyophilization. (b, c) LCMS negative ionization mass spectra (M-1) of the compounds detected at: (b) Retention time $=8.43 \mathrm{~min}$ and $(\mathrm{c})$ Retention time $=9.19 \mathrm{~min}$. Red-boxed ion is fragmented to create the next generation. For LC, the eluent was water + formic acid $(0.01 \mathrm{wt} . \%)$, the flow rate was $0.6 \mathrm{~mL}$ $\min ^{-1}$, and the column was Aminex HPX-87H. 
Fig. 8. LC-MS results of the galvanostatic operation of the DGFC at $j=1 \mathrm{~mA} \mathrm{~cm}{ }^{-2}$ for 2 hours $\left(\right.$ anode $=\mathrm{Au}_{50} \mathrm{Pt}_{50} / \mathrm{rGO}\left(0.2 \mathrm{mg}_{\text {metal }} \mathrm{cm}^{-2}\right) ;$ cathode $=\mathrm{Pt} / \mathrm{Vulcan}\left(0.2 \mathrm{mg}_{\text {metal }} \mathrm{cm}^{-2}\right)$; membrane $=$ Fumatech AEM; anode $=0.1 \mathrm{M} \mathrm{KOH}+50 \mathrm{mM}$ glucose $;$ and cathode $=0.1 \mathrm{M}$ $\mathrm{KOH}+\mathrm{O}_{2}$ bubbling). (a-c) LC-MS negative ionization mass spectra (M-1) of the compounds detected at: (a) Retention time $=6.90 \mathrm{~min}$, (b) Retention time $=7.92 \mathrm{~min}$ and (c) Retention time $=9.85 \mathrm{~min}$. Red-boxed ion is fragmented to create the next generation . 
Figure 1

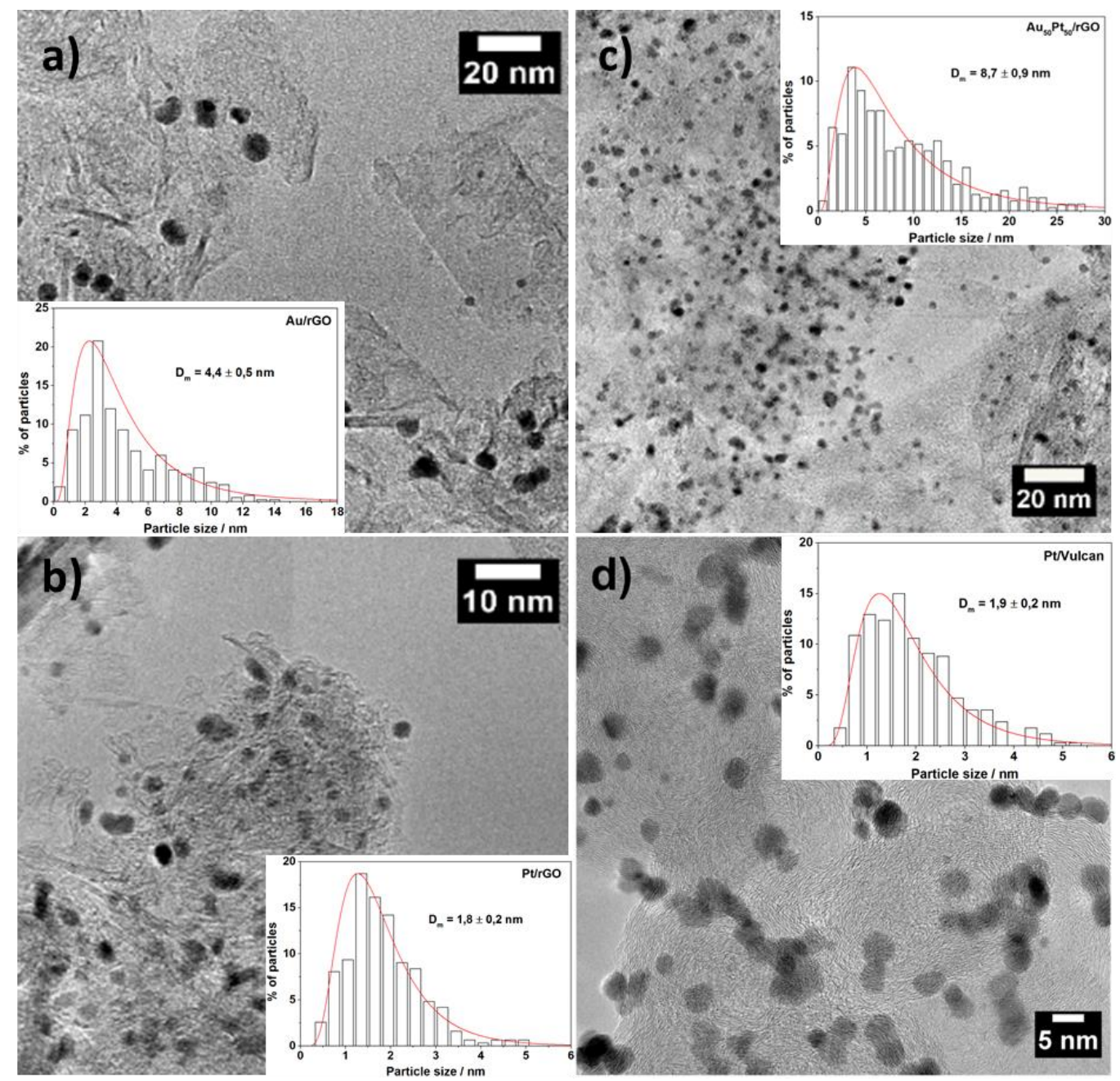


Figure 2
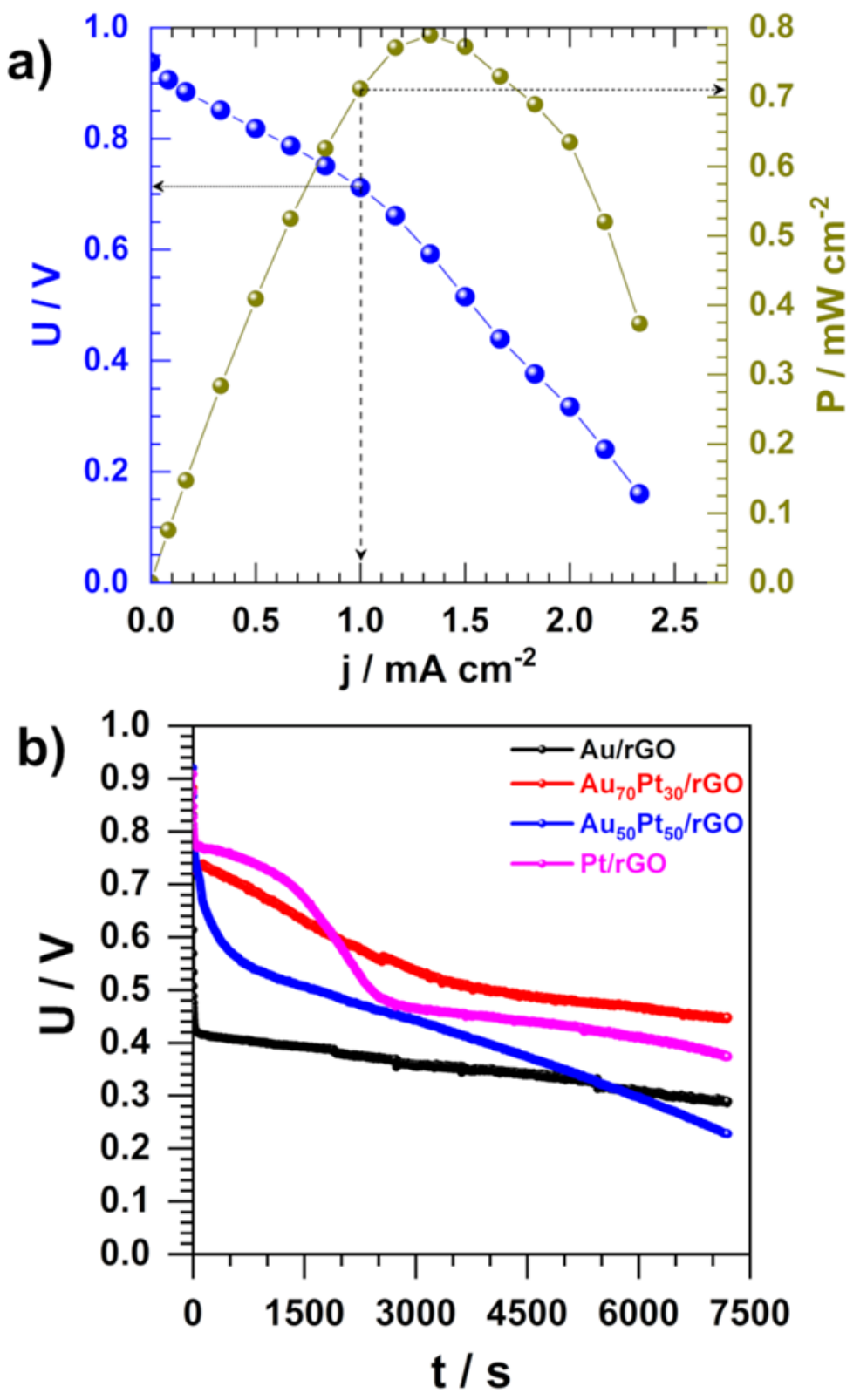


\section{Figure 3}
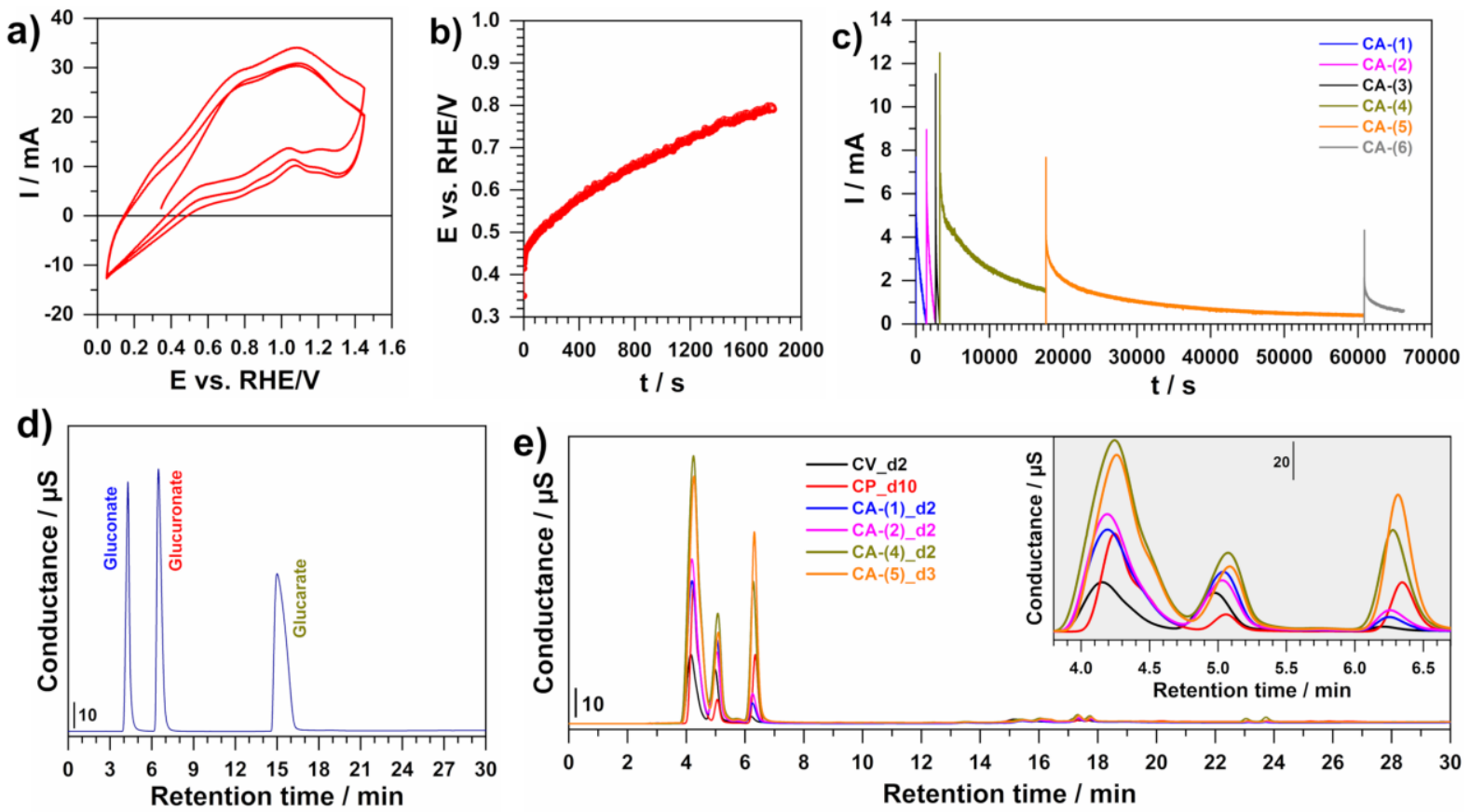


\section{Figure 4}
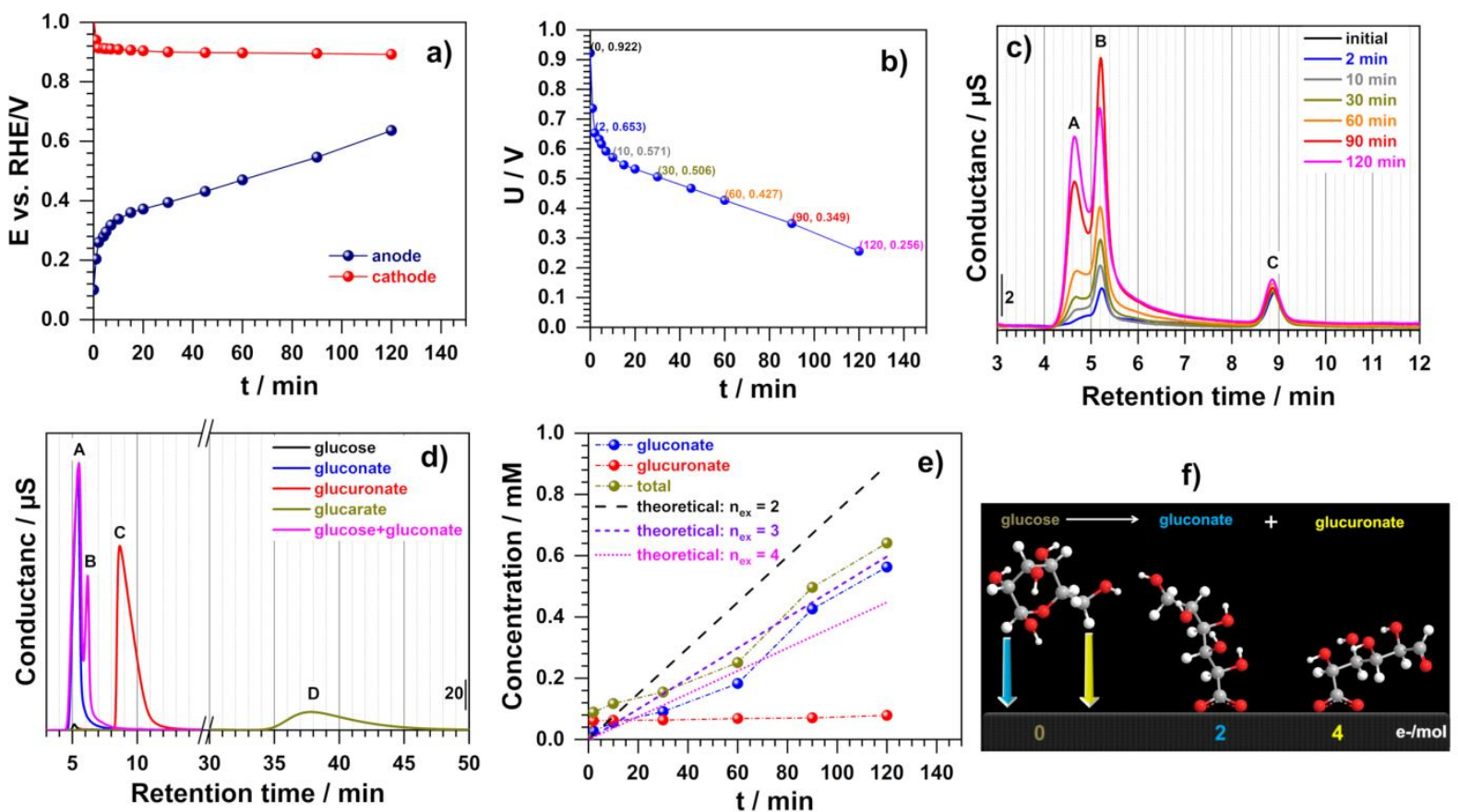
Figure 5

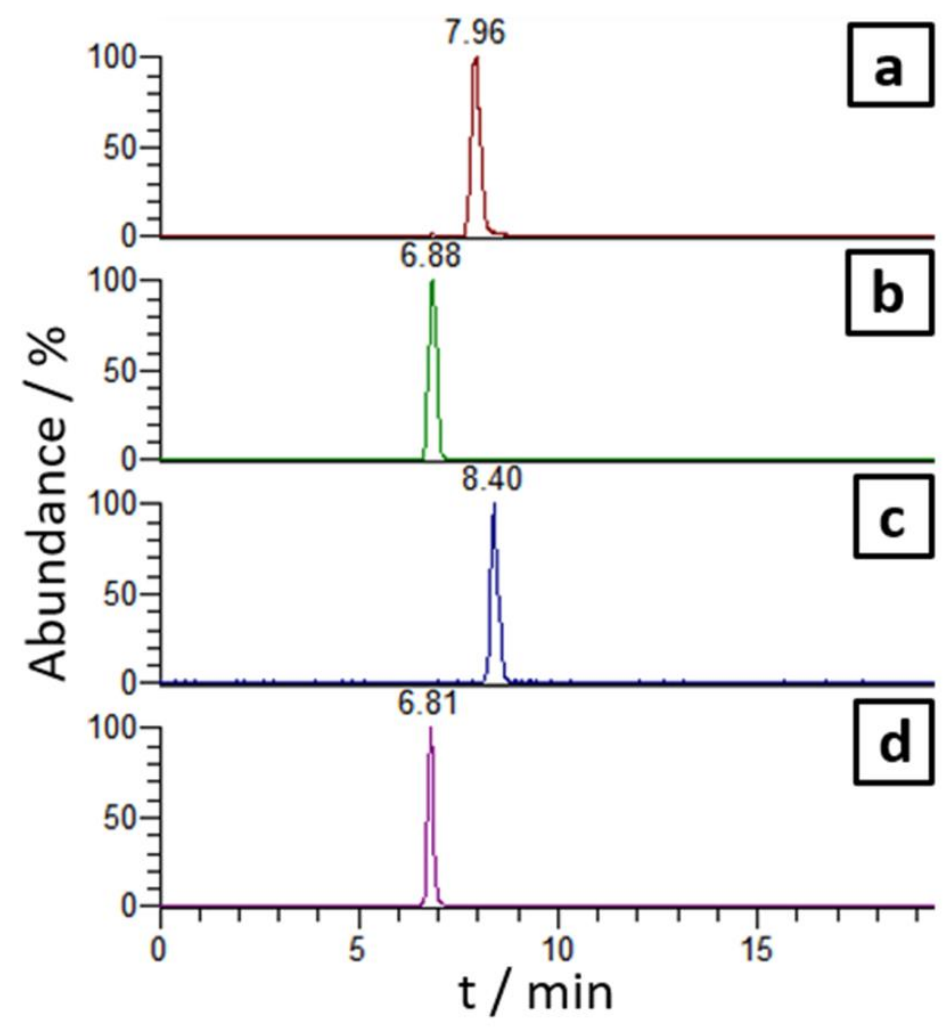


Figure 6
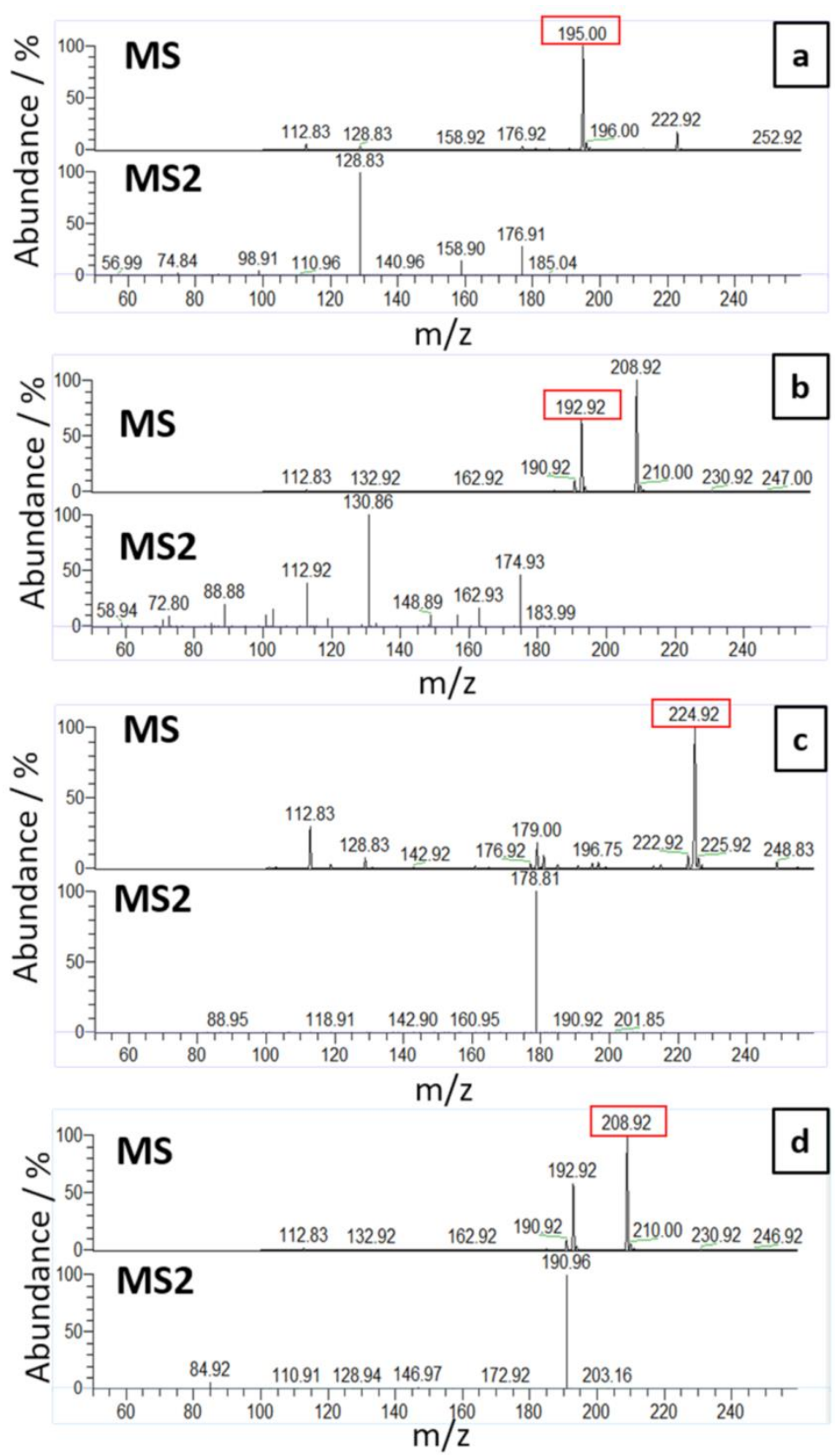
Figure 7
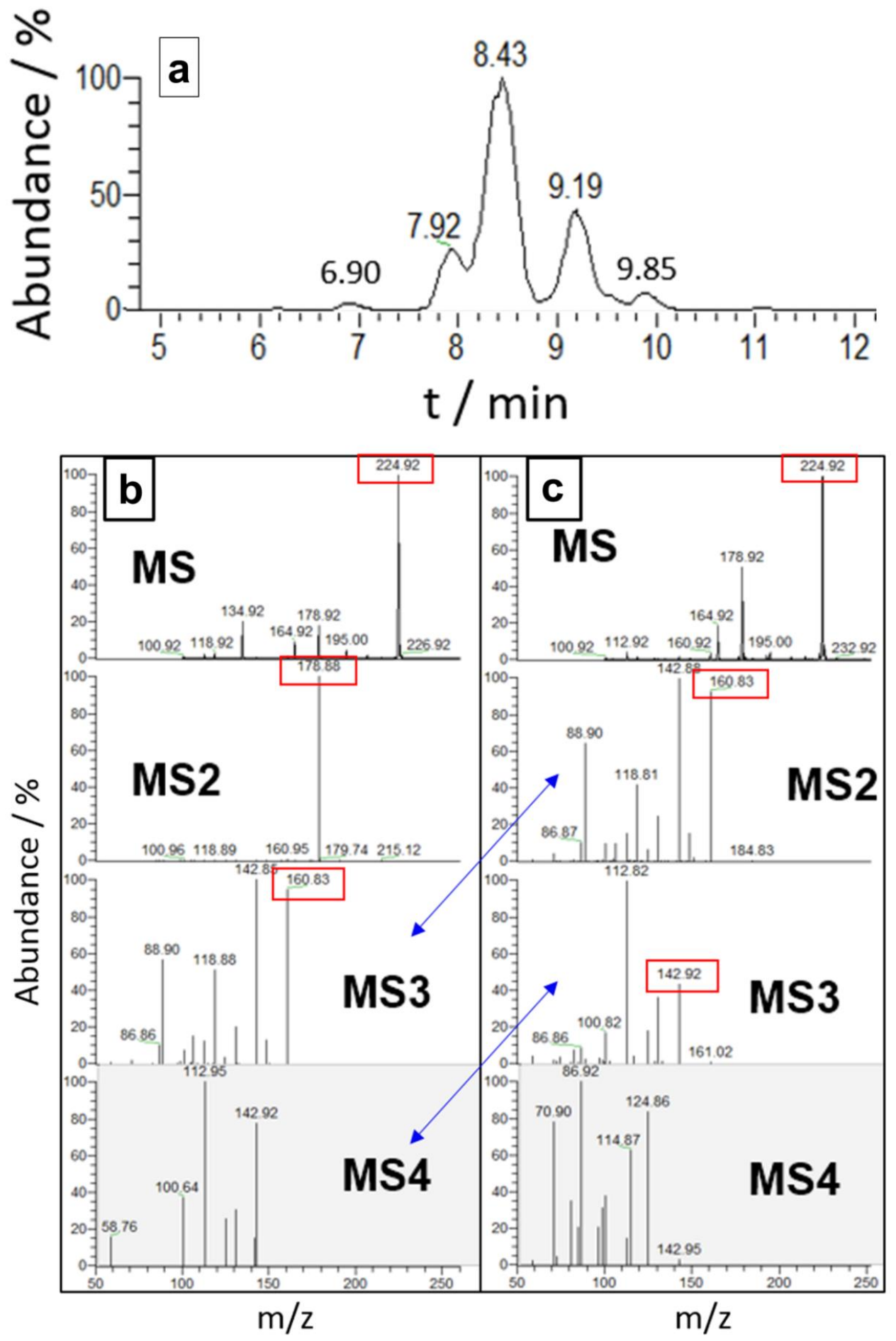
Figure 8
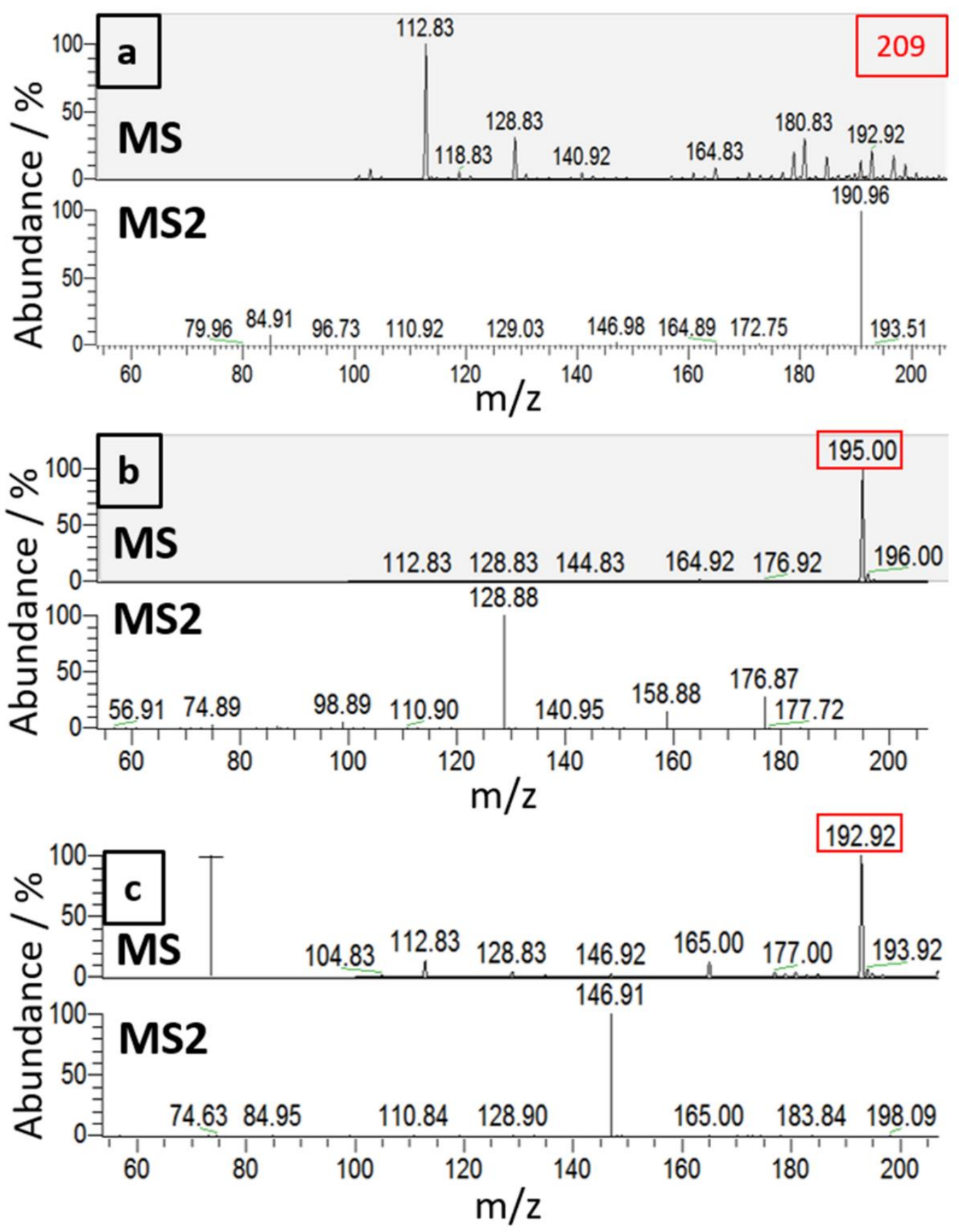